Vol. 6, No. 1, 2021, pp. 95-99

Contents lists available at \ournal IICET

JRTI (Jurnal Riset Tindakan Indonesia)

ISSN: 2502-079X (Print) ISSN: 2503-1619 (Electronic)

\title{
Kebijakan pendidikan: kerangka, proses dan strategi
}

\author{
Linda Sari Oktavia ${ }^{1}$, Nurhidayati Nurhidayati ${ }^{1}$, Nurhizrah Gistituati $^{1}$ \\ ${ }^{1}$ Universitas Negeri Padang, Indonesia
}

\begin{tabular}{l} 
Article Info \\
\hline Article history: \\
Received Apr $17^{\text {th }}, 2021$ \\
Revised May $13^{\text {th }}, 2021$ \\
Accepted Jun $16^{\text {th }}, 2021$ \\
\hline
\end{tabular}

\section{Keyword:}

Kebijakan pendidikan

Kerangka

Proses

Strategi

\begin{abstract}
Kebijakan pendidikan merupakan hasil akhir dari sebuah keputusan dibidang pendidikan yang diambil dengan memperhatikan komponen-komponen pendidikan dan komponen sosial yang berkaitan. Untuk menghasilkan kebijakan pendidikan yang tepat maka penyelenggara pendidikan harus mampu mengetahui hakikat kebijakan pendidikan terutama yang berhubungan dengan kerangka kerja pengembangan kebijakan pendidikan. Oleh sebab itu tujuan penulisan artikel ini adalah untuk mengkaji kerangka kerja pengembangan kebijakan pendidikan, proses analisis kebijakan pendidikan, dan strategi implementasi kebijakan pendidikan. Metodologi penulisan ini menggunakan metodologi studi kepustakaan. Penulisan artikel ini dilakukan dengan mengkaji sebanyak 26 jurnal nasional yang berhubungan dengan kebijakan pendidikan yang terdapat pada data base google scholar. Hasil dari pengkajian kemudian di jabarkan melalui artikel ilmiah. Dalam mengembangkan kebijakan pendidikan diperlukan kerangka pengembangan diantaranya yaitu infromasi kebijakan, metode perolehan informasi, argumentasi kebijakan dan bentuk analisis kebijakan. Selain itu ada enak tahapan analisis kebijakan pendidikan yang terdiri dari inisiasi, estimasi, seleksi, implementasi, evaluasi dan terminasi. Untuk menerapkan sebuah kebijakan pendidikan maka diperlukan tahapan sosialisasi, tahapan piloting, dan tahapan desiminasi.
\end{abstract}

(C) 2021 The Authors. Published by IICET.

This is an open access article under the CC BY-NC-SA license

(https://creativecommons.org/licenses/by-nc-sa/4.0)

\section{Corresponding Author:}

Linda Sari Oktavia,

Universitas Negeri Padang

Email: lindasari121078@gmail.com

\section{Pendahuluan}

Undang-undang nomor 20 tahun 2003 mengenai sistem pendidikan nasional Indonesia telah menetapkan bahwa segala bentuk proses pendidikan yang ada dinegara Indonesia harus dilaksanakan dan dikembang secara maksimal agar tercapainya tujuan pendidikan yang telah ditetapkan (Hakim, 2016). Berdasarkan undang-undang tersebut tujuan pendidikan nasional yaitu menjadikan setiap warga negara memiliki wawasan keilmuan yang luas serta memiliki kepribadian yang luhur berlandaskan pancasila. Artinya bahwa tujuan pendidikan nasional di Indonesia menjadikan setiap warga negara menguasai aspek pengetahuan dan aspek keterampilan yang dilandasi oleh aspek sikap yang baik. Maka untuk mencapai tujuan pendidikan tersebut diperlukan pengelolaan dan pengawasan mutu yang maksimal.

Pengelolaan mutu pendidikan nasional merupakan bagian penting yang harus dilakukan dalam proses manajemen pendidikan (Fitra, 2017). Proses pengelola mutu pendidikan ini dapat dituangkan kedalam proses manejemen mutu pendidikan (Puspitasari, 2018). Manajemen mutu pendidikan pada dasarnya bertujuan untuk memberikan pelayanan yang baik kepada pelanggan agar pelanggan merasa nyaman dalam mencapai 
tujuan pendidikan (Sila, 2017). Pada hal ini yang menjadi pelanggan pendidikan adalah guru, siswa, orang tua dan masyarakat. Maka penyelenggara pendidikan (pemerintah) harus mampu memberikan pelayanan terhadap masyarakat.

Agar dapat memberikan pelayanan yang baik maka penyelenggara pendidikan harus dapat memahami aspirasi, kebutuhan dan karakteristik masyarakat (Mustaqin, 2016). Pendidikan diharapkan mampu memberikan pelayanan secara nyata kepada masyarakat baik dari tingkat pusat bahkan harus juga memberikan pelayanan kepada masyarakat yang berada pada daerah (Purba et al, 2021). Artinya diperlukan upaya untuk menjalin komunikasi dengan stakeholders dalam pendidikan agar penyelenggara pendidikan dapat merumuskan kebijakan dan mengambil keputusan yang berhubungan dengan perluasan dan pemerataan layanan pendidikan,peningkatan mutu dan relevansi pendidikan serta mengoptimalkan proses pengelolaan pendidikan. Ha ini lah yang menjadi pandangan baru dalan proses pengelolaan pendidikan bahwa perlunya gagasan yang bersifat desentralisasi agar pengelolaan pendidikan dilakukan secara bersamaan antara pemerintah pusat dengan pemerintah daerah.

Pengelolaan pendidikan bukan lah hal yang mudah (Aziz, 2015). Diperlukannya proses perumusan kebijakan dan pengambilan keputusan yang tepat (Muhdi et al, 2017). Penyelenggara pendidikan harus benarbenar paham mengenai hakikat kebijakan pendidikan (Nurhardjadmo, 2008). Kebijakan pendidikan yang dilahirkan tidak hanya saja bersifat pada golongan tertentu namun akan memiliki dampak yang besar terhadap kehidupan masyarakat (Bakry, 2010). Kebijakan pendidikan yang dihasilkan dengan proses yang tepat akan menghasilkan luaran yang akan mampu mencapai tujuan pendidikan yang telah disepakati dan apabila kebijakan pendidikan yang dihasilkan tanpa adanya proses yang bersifat prosedural maka akan berdampak kepada mutu pendidikan (Winarsih, 2017).

Untuk menghasilkan kebijakan pendidikan yang tepat maka penyelenggara pendidikan harus mampu mengetahui hakikat kebijakan pendidikan terutama yang berhubungan dengan kerangka kerja pengembangan kebijakan pendidikan. Oleh sebab itu tujuan penulisan artikel ini adalah untuk mengkaji kerangka kerja pengembangan kebijakan pendidikan, proses analisis kebijakan pendidikan, dan strategi implementasi kebijakan pendidikan.

\section{Metode}

Metodologi penulisan ini menggunakan metodologi studi kepustakaan. Penulisan artikel ini dilakukan dengan mengkaji sebanyak 26 jurnal nasional yang berhubungan dengan kebijakan pendidikan yang terdapat pada data base google scholar. Hasil dari pengkajian kemudian di jabarkan melalui artikel ilmiah.

\section{Hasil dan Pembahasan}

Kebijakan pendidikan merupakan hasil akhir dari sebuah keputusan dibidang pendidikan yang diambil dengan memperhatikan komponen-komponen pendidikan dan komponen sosial yang berkaitan (Solichin, 2015). Kebijakan pendidikan yang dilahirkan harus bersifat intredisipliner dan kontekstual (Asmawi, 2018). Untuk dapat melahirkan kebijakan pendidikan maka diperlukan analisis kebijakan pendidikan yang tepat. Analisis kebijakan pendidikan merupakan cara untuk memecahkan permasalahan yang berhubungan dengan pendidikan melalui pendeiatan ilmu sosial terapan dengan menggunakan metode inguiri dan argumen ganda.

Pembuatan kebijakan tidak terlepas hari hal yang bersifat politis dikarenakan dalam pembuatan kebijakan akan terjadi proses pertentangan antar kelompok yang mempunyai kepentingan yang berbeda-beda (Sarmoto, 2013). Maka dalam pengembangan kebijakan pendidikan tersebut harus mampu mengalahkan ego pribadi dan kelompok sehingga pertentangan yang terjadi bersigat netral dan objektif. Oleh sebab itu para pembuat kebijakan pendidikan harus mampu memahami kerangka kerja pengembangan kebijakan pendidikan, proses analisis kebijakan pendidikan, dan strategi implementasi kebijakan pendidikan agar terciptanya kebijakan pendidikan yang tepat sasaran.

\section{Kerangka Kerja Pengembangan Kebijakan Pendidikan}

Analisis kebijakan merupakan proses pengimplementasian ilmu sosial dengan menggunakan bentuk pemikiran, penalaran, pembuktian, penilaian dan pemecahan masalah yang berhubungan dengan masyarakat luas (Alam, 2012). Agar dapat menghasilkan pandangan yang rasional diperlukan sebuah prosedur analisis. Adapun prosedur tersebut adalah: 1) Informasi Kebijakan. Pada proses informasi kebijakan terdapat 3 jenis informasi yang harus dilahirkan yaitu informasi mengenai (Afifah dan Yuningsih, 2016); 2) Nilai. Infromasi mengenai nilai berhubngan dengan bagamanakah proses nilai yang terdapat pada kebijakan tersebut; 3) Fakta. Informasi tentang fakta berhubungan dengan apakah hal yang dibicarakan tersebut ada atau tidak ada; 4) 
Perbuatan. Informasi tentang perbuatan berhubungan dengan apa yang harus dilakukan terhadap permasalahan tersebut.

Masing-masing infromasi akan menghasilkan luaran yang berbeda. Pertanyaan yang berkaitan dengan nilai akan mendapatkan infomasi yang bersifat evaluatif, untuk pertanyaann yang berkaitan dengan fakta akan mendapatkan infromasi yang bersifat deskriptif dan pertanyaan normatif akan mendapatkan informasi yang bersifat pembenaran (pembelaan).

\section{Metode Perolehan Informasi}

Pada proses penganalisisan kebijakan adanya keterkaitan antara prosedur analitik dengan empat metode yaitu pemantauan (monitoring), peramalan (prediksi), penilaian (evaluasi), dan pemberian rekomendasi, . Selain itu ada 2 metode lain yang dapat digunakan namun tidak dapat dikelompokan kedalam metode tersebut yaitu problem structuring (penstrukturan masalah) yang merupakan fase dalam proses analisis kebijakan yang menganggap adanya situasi yang menganggu dalam sebuah suasana. Selanjutnya yaitu metode inferensi praktis yang artinya bahwa pengambilan sebuah keputusan berdasarkan sejauh mana permasalahan yang berhubungan dengan kebijakan di pecahkan (Darwis, 2014).

\section{Argumentasi Kebijakan}

Suatu kebijakan berhubungan dengan proses meyakinkan masyarakat mengenai fungsi kebijakan, (Damayanti, 2017). Dalam proses meyakinkan ini maka diperlukanya pengubahaan informasi kebijakan menjadi argumentasi kebijakan. Adapun komponen dalam argumentasi kebijakan tersebut yaitu: 1) Informasi yang berhubungan dengan kebijakan; 2) Klaim kebijakan. Keputusan dari argumentasi kebijakan; 3) Pembenaran. Pembenaran dapat berupa intuitif, otoritatif, sebab-akibat, analisentrik, dan prigmatik (penilaian); 4) Pendukung yaitu semua data yang dapat membenarkan infromasi dapat berupa data ilmiah, usulan pakar ahli, prinsip etis dan moral; 5) Kriteria yaitu yang dapat menyamakan sejauh mana analisi diyakini mengenai klain sebuah kebijakan.

\section{Bentuk Analisis Kebijakan}

Terdapat tiga bentuk analisis kebijakan yaitu a) Tipe prospektif. Tipe ini adalah tipe yang melakukan analisis kebijakan yang dilakukan sebelum kebijakan tersebut dilaksanakan (Alam, 2012). b) Tipe retrospektif. Tipe ini adalah tipe yang melakukan analisis kebijakan setelah kebijakan tersebut dilaksanakan (Dewi, 2020). c) Tipe integratif. Tipe ini adalah tipe yang melakukan analisis kebijakan sebelum dan sesudah kebijakan tersebut dilaksanakan (Aziz et al, 2020).

Maka dari penjelasan kerangka kerja pengembangan kebijakan pendidikan tersebut dapat terlihat bahwa sebuah kebijakan dilahirkan dengan proses yang sistematis.

\section{Proses Analisis Kebijakan Pendidikan}

Dalam proses analisis kebijakan terdapat proses yang harus dilaksanakan oleh pembuat kebijakan. Proses ini bertujuan agar kebijakan yang dilahirkan sesuai dengan permasalahan yang dihadapi. Adapun proses analisis kebijakan tersebut yaitu, (Keban, 2015):

\section{Inisiasi}

Tahap inisiasi diawali ketika adanya masalah yang bersifat potensial. Permasalahan potensial tersebut dirasakan ketika adanya upaya untuk mengurangi permasalahan yang bertujuan untuk memecahan permasalahan tersebut secara tepat. Pada fase ini belum dituntut untuk dapat merumuskan permasalahan namun diperlukan sebuah pemikiran lebih lanjut apakah permasalahan ini diperlukan untuk dirumuskan. Pada tahap ini juga dilakukan proses inovasi dalam melakukan konseptualisasis dan membuat kerangkan permasalahan secara umum. Selain itu juga diperlukan pengumpulan infromasi yang berkaitan dengan kebijakan secara umum dan memprediksi pilihan-pilhan kebijakan yang dirasa dapat untuk dikembangkan.

\section{Estimasi}

Pada tahapan estimasi ini diperlukan pemikiran yang berhubungan dengan dampak, pembiayaan dan kelebihan dari alternatif yang disajikan. Pada tahapan ini masalah di fokuskan dengan menggunakan metode olian yang bersifat proyektif dan empirik agar dapat diketahuinya dampak yang ditimbulkan dari kebijakan yang dipilih. Pengkajian juga difokuskan kepada evaluasi terhada luaran yang akan dihasilkan melalui pendekatan teknis lainnya.

\section{Seleksi}

Tahapan seleksi ini berkaitan dengan keputusan. Setelah dilakukan analisis kebijakan berupa perumusan dan penilaian kebijakan maka diperlukanlah pemilihan kebijakan. Pengambilan keputusan sering kali dilahirkan dengan perhitungan dan perkiraan teknis namun adanya aspek lain yang perlu diperhatika seperti keterlibatan pihak-pihak lain yang memiliki tjuan yang berbeda mengenai pandang ideologi, mora dan kerangka acuan. 


\section{Implementasi}

Tahapan implementasi merupakan tahapan melaksanakan pilihan yang telah disepakati. Tahapan implementasi merupakan saran untuk melakukan uji kelayakan pilihan yang dipilih secara nyata. Pada tahapan sebelumnya kebijakan masih dalam bentuk pemikran sedangkan pada tahapan implementasi ini kebijakan dapat dilaksanakan secara nyata.

\section{Evaluasi}

Pada tahapan inisiasi dan estimasi, sifat tahapan bersifat antisipatif sedangkan pada tahapan seleksi lebih bersifat kekinian. Pada tahapan implementasi lebih bserfiat transformasi kedalam dunia nyata sedangkan pada tahapan evaluasi lebih bersifat restrospektif. Pada tahapan ini berusaha untuk menemukan jawaban mengenai sejauh mana kebijakan yang dipilih berhasil. Pada tahapan ini dilakukan pengukuran dengaan indikator yang telah dilakukan.

\section{Terminasi.}

Tahapan terminasi adalah tahapan yang menyesuaikan kebijakan yang tidak diperlukan dengan keadaan.

Berdasarkan pemaran tersebut terlihat bahwa proses kebijakan merupakan proses yang kompleks. Proses kebijakan ini melibatkan berbagai individu, kelompok dan masyarakat dengan psiklogis dan lingkungan yang berbeda-beda. Namun tahapan ini perlu dilaksanakan dengan baik agar dapat dihasilkanya kebijakan yang pro aktif dan problem solving.

\section{Strategi Implementasi Kebijakan Pendidikan}

Pengelolaan pendidikan yang bersifat desentralisasi di Indonesia memungkinkan terjadinya perumusan kebijakan dan pengembilan keputusan yang melibatkan unsur pemerintah pusat dan unsur pemerintah daerah (Aulia, 2013). Dalam proses pendidikan diberikanyan kesempatan dan wewenang kepada stakeholder pendidikan dan masyarakat berpartisipasi aktif dalam memajukan lembaga pendidikan (sekolah)

Praktek kebijakan pendidikan dituangkan dalam sebuah pengelolaan yang dikenal dengan manajemen berbasis sekolah (MBS) (Athiyah, 2019). Pada sistem MBS ini terjadinya penyerahan wewenang pengelolaan sekolah kepada sekolah dan stakeholder yang terkait, (Ismali, 2018). Maka perlu diketahuinya strategi pengelolaan pendidikan di sekolah secara merata meskipun konsep pengelolaanya bersifat desentralisasi. Adapun tahapan tersebut yaitu (Huda et al, 2020):

\section{Tahap sosialisasi}

Tahapn sosialisasi meruakan tahapanyang penting karena diperlukannya penyebaran kebijakan yang merata kesetiap daerah yang ada di Indonesia. Penyebaran informasi ini dapat dilakukan secara online maupun offline. Adapun yang menjadi tantangan dalam tahapan sosialisasi ini adalah masyarakat sulit menerima adanya perubahan sehingga diperlukan waktu yang lama untuk adaptasi. Maka dalam memaksimalkan perubahan kebijakan tersebut diperlukan pertimbangan dengan memperhatikan aspek tujuan, manusia, lingkungan , proses, hasil dan kebiasaan.

\section{Tahap piloting}

Tahapan pilotting ini bertujuan untuk mengurangi dampak yang ditimbulkan dari uji coba kebijakan sehingga diperlukan model uji coba. Model uji coba ini jatus memenuhi syarat yaitu akseptabilitas, akuntabilitas, replikablitas dan sustainabilitas.

\section{Tahap diseminasi}

Tahapan diseminasi merupakan tahapan penyebaran secara luas kebijakan yang ditetapkan. Perlu diperhatikan bahwa tahapan disiminasi ini memerlukan fasilitas yang banyak dan anggaran yang besar.

Ketiga tahapan ini perlu dikembangkan agar kebijakan yang telah dihasilkan dapat laksanakan secara menyeluruh.

\section{Simpulan}

Dari studi kepustakaan yang dilakukan maka didefinsikaan bahwa kebijakan pendidkaan merupakan suatu keputusan yang berhubungan dengan memecahkan permasalaha yang berhubungan dengan sistem pendidikan. Dalam pengembangan kebijakan pendidikan yang harus diperhatikan adalah informasi kebijakan, metode perolehan informasi, argumentasi kebijakan dan bentuk analisis kebijakan. Agar kebijakan dapat terlaksana dengan baik maka perlunya tahapan pelaksanaan yang terdiri dari tahapan sosialisasi, tahapan piloting, dan tahapan desiminasi. Setiap tahapan harus dilaksanakan dengan optimal agar lahirnya kebijakan yang sesuai dengan harapan. 


\section{Referensi}

Afifah, D. F., \& Yuningsih, N. Y. (2016). Analisis Kebijakan Pemerintah Tentang Pencegahan Dan Penanganan Korban Perdagangan (Trafficking) Perempuan Dan Anak Di Kabupaten Cianjur. Jurnal Ilmu Pemerintahan ISSN, 2442, 5958.

Alam, A. S. (2012). Analisis kebijakan publik kebijakan sosial di perkotaan sebagai sebuah kajian implementatif. Jurnal Ilmiah Ilmu Pemerintahan, 1(3), 78-92.

Asmawi, M. N. (2018). Kebijakan Pendidikan Islam Pada Era Globalisasi, Pasar Bebas dan Revolusi Industri 4.0. Jurnal Scolae: Journal of Pedagogy, 1(2), 1-10.

Athiyah, C. U. (2019). Implementasi Manajemen Berbasis Sekolah Sebagai Alternatif Desentralisasi Pendidikan di MAN 4 Jakarta. Andragogi: Jurnal Diklat Teknis Pendidikan dan Keagamaan, 7(1), 130-145.

Aulia, S. (2013). Desentralisasi Kebijakan pendidikan (studi tentang pelaksanaan wajib belajar 12 tahun di kota surabaya pada tingkat pendidikan menengah dan kejuruan). Jurnal Politik Muda, 2(1).

Aziz, A. (2015). Peningkatan mutu pendidikan. Jurnal Studi Islam, 10(2), 1-13.

Aziz, A. A., Nurfarida, R., Budiyanti, N., \& Zakiah, Q. Y. (2020). Model Analisis Kebijakan Pendidikan. Tapis: Jurnal Penelitian Ilmiah, 4(2), 192-201.

Bakry, A. (2010). Kebijakan Pendidikan Sebagai Kebijakan Publik. Jurnal Medtek, 2(1), 1-13.

Damayanti, S. N. (2017). Analisis Prospektif Kebijakan Pengalihan Kewenangan Pendidikan Menengah dari Pemerintah Kota Surabaya ke Pemerintah Provinsi Jawa Timur Berdasarkan UU No. 23 Tahun 2014 Tentang Pemerintahan Daerah. Kebijakan dan Manajemen Publik, 5(3), 1-12.

Darwis, A. (2014). Model Implementasi Kebijakan Pengembangan Ilmu Berparadigma Islami Dalam Akselerasi Pencapaian Visi Dan Misi Konversi Iain Susqa Pekanbaru Ke Uin Suska Riau. Jurnal Tarbiyah, 21(1), 1-10

Dewi, D. C. (2020). Kajian Retrospektif Kebijakan Peraturan Daerah Nusa Tenggara Barat Nomor 2 Tahun 2016 Tentang Pariwisata Halal. Jurnal MD, 6(2), 175-192.

Fitrah, M. (2017). Peran kepala sekolah dalam meningkatkan mutu pendidikan. Jurnal Penjaminan Mutu, 3(1), 31-42.

Hakim, L. (2016). Pemerataan akses pendidikan bagi rakyat sesuai dengan amanat Undang-Undang Nomor 20 Tahun 2003 tentang Sistem Pendidikan Nasional. EduTech: Jurnal Ilmu Pendidikan Dan Ilmu Sosial, 2(1), 1-10

Huda, M. M., Fitrotun, N. N., \& Fikri, A. A. (2020). Persepsi Calon Guru PAI Terhadap Merdeka Belajar. TADRIS: Jurnal Pendidikan Islam, 15(2).

Ismail, F. (2018). Manajemen Berbasis Sekolah: Solusi Peningkatan Kcalitas Pendidikan. Jurnal Ilmiah Iqra', 2(2), 1-10.

Keban, P. (2015). Terminasi Kebijakan Publik: Tinjauan Normatif. Jejaring Administrasi Publik, 2(1), $799-803$.

Muhdi, M., Kastawi, N. S., \& Widodo, S. (2017). Teknik Pengambilan Keputusan Dalam Menentukan Model Manajemen Pendidikan Menengah. Kelola: Jurnal Manajemen Pendidikan, 4(2), 135-145.

Mustaqim, M. (2016). Partisipasi Masyarakat dalam Meningkatkan Mutu Pendidikan. Al-Mabsut: Jurnal Studi Islam dan Sosial, 10(1), 245-275.

Nurharjadmo, W. (2008). Evaluasi implementasi kebijakan pendidikan sistem ganda di sekolah kejuruan. Spirit Publik, 4(2), 215-228.

Purba, S, et al. (2021). Analisis Kebijakan Pendidikan. Jakarta: Yayasan Kita Menulis.

Puspitasari, H. (2018). Standar proses pembelajaran sebagai sistem penjaminan mutu internal di sekolah. Muslim heritage, 2(2), 339-368.

Sa'ud, U. S., \& Sumantri, M. (2007). Pendidikan dasar dan menengah. Dalam Ilmu \& Aplikasi Pendidikan Bagian, 4.

Sarnoto, A. Z. (2013). Konsepsi politik pendidikan di Indonesia. Jurnal Educhild: Pendidikan dan Sosial, 1(1), 30-40.

Sila, I. M. (2017). Peranan Manajemen Mutu Pendidikan Tinggi Berbasis SPMI Dalam Meningkatkan Pelayanan Untuk Mewujudkan Pendidikan Berkualitas. Widya Accarya, 8(2), 1-10.

Solichin, M. (2015). Implementasi Kebijakan Pendidikan Dan Peran Birokrasi. Religi: Jurnal Studi Islam, 6(2), 148-178.

Winarsih, S. (2017). Kebijakan dan Implementasi Manajemen Pendidikan Tinggi dalam Meningkatkan Mutu Pendidikan. Cendekia: Jurnal Kependidikan Dan Kemasyarakatan, 15(1), 51-66. 